\title{
Influence of Working Depth and Soil Type on Drawbar Performance of a Chisel Plow
}

\author{
José F. Schlosser ${ }^{1}$, Paula M. dos Santos ${ }^{2}$, Daniela Herzog ${ }^{1}$, Lucas S. da Rosa ${ }^{1} \&$ Jaqueline Ottonelli $^{1}$ \\ ${ }^{1}$ Department of Rural Engineering, Federal University of Santa Maria, Santa Maria, Brazil \\ ${ }^{2}$ Departament of Soils, Federal Institute Farroupilha, Júlio de Castilhos, Brazil \\ Correspondence: José F. Schlosser, Department of Rural Engineering, Federal University of Santa Maria, \\ Avenida Roraima, 1000, Centro de Ciências Rurais, $3^{\circ}$ andar, Sala 3325, Santa Maria, RS, Zip Code: 9710-900, \\ Brazil. E-mail: josefernandoschlosser@gmail.com
}

Received: June 3, 2019 Accepted: July 25, $2019 \quad$ Online Published: September 30, 2019

doi:10.5539/jas.v11n16p206 URL: https://doi.org/10.5539/jas.v11n16p206

\begin{abstract}
With the aim of studying the drawbar performance and power required by a commercial chisel plow with five shanks, an experiment was carried out involving two soil types (sandy and clayey) and three working depths $(0.25,0.35$ and $0.45 \mathrm{~m})$. A farm wheeled tractor, properly sized by the raw power of the engine, pulled the equipment. An electronic instrumentation was used for data acquisition to measure the drawbar pull. Furthermore, in addition, four other parameters were determined, as real travel speed and slippage of the tractor. Chiseling operations showed no statistically significant effect of soil type on drawbar pull in the different working depths. However, clayey soil presented higher values of slippage (34.44\%), power performance (47.25 $\mathrm{kW})$ and drawbar pull $(40.26 \mathrm{kN})$ than sandy soil.
\end{abstract}

Keywords: agricultural machinery, chiseling, conservation tillage

\section{Introduction}

Several farming systems have provided the acceleration of soil degradation, with the consequences of physical, chemical and biological imbalances of soil and negatively interfering on crop yield potential (Filho, Centurion, Silva, Furlani, \& Carvalho, 2007; Celik et al., 2017). The selection of the proper equipment to perform certain agricultural operation in each soil condition is an indispensable factor in the efficient planning of rural properties, both in the economic and environmental aspect, and it is important to emphasize that these operations use significant energy, mostly non-renewable, jeopardizing the future of agriculture.

Chisel plow is an important agricultural implement used for the preparation and improvement of soil physical conditions, and was introduced in the mechanization of crops in the $80 \mathrm{~s}$ as a tool for the conservation method, alternative to conventional tillage. These implements are often confused and erroneously called subsoilers, and often used in the east and southern regions of Brazil. They search for suitable conditions for the development of the crops to be implanted, with minimum tillage, and without the incorporation of most crop residues, unlike what occurs with the use of other implements.

In a work carried out in a Haplustox soil, chiseling was the most suitable soil preparation as practice of conservation because it provides large soil aggregates and high maintenance of cultural residues on soil surface (Filho et al., 2007).

Different equipment manufacturers have developed chisel projects based on international models and have introduced them as frequently used equipment. In most cases, the effects and advantages of its use were not clear, as well as the characteristics of suitable adjustments and power source design for its traction pull. However, for the efficient use of a chisel plow (Machado, Machado, Turatti, Reis, \& Alonço, 1996), it is extremely important make an analysis of the parameters related to soil tillage and implement performance in several conditions. The main physical properties of soil that suffer through the process of compaction are soil density, porosity and hydraulic conductivity, which also affect the development of the plant root system (Gregory et al., 2015). Thus, even under no tillage planting, the use of techniques, such as chiseling to break compacted layers of soil, may be needed. 
As for tillage depth, small changes can cause large variations in the traction pull required (Bianchini et al., 1999), influencing fuel consumption, power consumption, wear and mechanical damage to tractors and implements (Unger \& McCalla, 1981; Souza, Rabelo, Cabacinha, Pinto, \& Matos, 2015). However, deep tillage is justified with increased yield by decompaction (Trouse Jr. \& Humbert, 1959; Bogunovic, Pereira, Kisic, Sajk, \& Sraka, 2018), especially for soils where compacted layers are limiting factors to the full development of crops due to the reduction of the effective depth.

Power losses are directly related to wheel traffic-soil relationship, and may vary according to the type of tire and soil physical properties. Such losses can be explained by the phenomenon of slippage (Márquez, 2012), causing reduction in the advancement of the tractor, and the repression of the wheelset which increases rolling resistance. Consequently, slippage level affects fuel consumption and the actual travel speed, also changing the drawbar power (Ranjbarian, Askari, \& Jannatkhah, 2017).

This experiment was conducted in order to determine drawbar pull and power by studying the influence of working depth and soil type on a chisel plow traction pull demand.

\section{Material and Methods}

The agricultural mechanized set used for this research, in both soils, consisted of a Massey Ferguson tractor MF 5310 , with $77.3 \mathrm{~kW}$ maximum power and front wheel drive (FWD), mass power ratio of $73 \mathrm{~kg} / \mathrm{kW}$, and a Stara CR-ASA LASER chisel plow with five shanks with $7.5 \mathrm{~cm}$ wide tool and spacing of $37.5 \mathrm{~cm}$ between units. For the experiment the tractor was equipped with diagonal tires, with the rear specification 18.4-34 R1 and the front 14.9-24 R1. The maximum weight of the tractor is approximately $5657 \mathrm{~kg}$, distributed between the axles with $2350 \mathrm{~mm}$ distance. A low reduced $3 \mathrm{rd}$ gear was used for the tractor at 1900 rated speed of the engine (theoretical travel speed of $5.54 \mathrm{~km} \mathrm{~h}^{-1}$ at $2200 \mathrm{rpm}$ ). The chisel plow used has a unique system of automatic disarm of units through coil springs.

This experiment was conducted in two soil types (first experimental factor) at different locations in the state of Rio Grande do Sul, Brazil:

(a) The first experimental location was the site of the University of Santa Maria, RS, Brazil. The climate of the region is considered to be CFA 2 according to the Köeppen classification, with average annual temperatures from $19.2{ }^{\circ} \mathrm{C}$ to $17.9^{\circ} \mathrm{C}$ and the average annual rainfall from 1404 to $1769 \mathrm{~mm}$. The soil, classified by EMBRAPA (1999) as typical Argissolo Vermelho Amarelo-Argissólico, with medium texture, and gently wavy relief, consisting of sandstone substrate. The experimental area was located in the upper third of a hill with average slope of $3 \%$, covered with stubble oat (Avena strigosa) $\left(1750 \mathrm{~kg} \mathrm{ha}^{-1}\right)$.

(b) The second experiment was conducted in the municipality of Não-Me-Toque, RS, Brazil. Soil is a Latossolo Vermelho Distroférrico Típico according to the Brazilian soil classification (EMBRAPA, 1999), wavy ground, and constituted of basaltic substrate. The mapping unit is Passo Fundo. The climate is CFA 1 according to the Köeppen classification with annual average temperatures below $18^{\circ} \mathrm{C}$ and average annual rainfall of $1750 \mathrm{~mm}$. The steepness of the terrain was less than $2 \%$ and the ground was covered with $3100 \mathrm{~kg} \mathrm{ha}^{-1}$ of stubble wheat (Triticum aestivum L.). The physical properties of both soils are shown in Table 1.

In each soil, samples with preserved structure (EMBRAPA, 1997) were taken, in the depths of: 0 to $0.10 ; 0.10$ to $0.20 ; 0.20$ to $0.30 ; 0.30$ to 0.40 ; and 0.40 to $0.50 \mathrm{~m}$. These samples were used to determine the apparent bulk density and plasticity limits (Atterberg boundaries) (Sowers, 1965). The penetration resistance of the soil was obtained through a penetrometer Falker brand, penetroLOG PLG1020 model, allowing to determine the average soil penetration resistance up to the depth of $0.50 \mathrm{~m}$, according the procedures established by the standard ASAE $\mathrm{S} 313.2$, as dimensions, operation and data measurement procedure. The samples were collected randomly at three sites of each soil.

At these depths, also were collected samples with non-preserved structure for the accomplishment of granulometric analysis. Three sub-samples were collected by treatment, which were mixed and homogenized forming a representative sample of each treatment and analyzed by the Soil Analysis Laboratory at UFSM using the Vettori granulometric analysis method described in Vettori (1969). From these results, an average result were presented as shown in Table 1.

The moisture content of the soil was obtained through the collection of three samples per treatment, which were submitted to the analysis that provided the gravimetric moisture of the samples. From these three samples the average water content of the soil was calculated. The gravimetric moisture was obtained according to EMBRAPA (1997), which establishes the following mathematical relation (1) to determine it, in wich: Ug = soil water content $(\%)$; PU = wet sample weight (g); PS = dry sample weight $(\mathrm{g})$. 


$$
\mathrm{Ug}=(\mathrm{PU}-\mathrm{PS} / \mathrm{PS}) \times 100
$$

Table 1. Soil physical properties of Argissolo Vermelho Amarelo-Argissólico (Sandy) (Santa Maria, RS) and Latossolo Vermelho Distroférrico Típico (Clayey) (Não-Me-Toque, RS)

\begin{tabular}{lll}
\hline Physical Properties & Sandy & Clayey \\
\hline Apparent density $\left(\mathrm{Mg} \cdot \mathrm{m}^{-3}\right)$ & 1.58 & 1.56 \\
Total porosity (\%) & 40.21 & 42.25 \\
Plastic upper limit (\%) & 22.28 & 33.50 \\
Plastic lower limit (\%) & 17.10 & 22.02 \\
Texture: Sand (\%); Silt (\%); Clay (\%) & $45.64 ; 38.24 ; 16.12$ & $35.65 ; 22.67 ; 41.96$ \\
Average Soil penetration resistance (kPa) & 381.47 & 635.47 \\
Moisture content of soil $(0-45 \mathrm{~cm})(\%)$ & 26.7 & 16.0 \\
\hline
\end{tabular}

For this assessment, the theoretical speed of the wheels and the slippage was acquired by the installation of sensors that measure the driving wheels rotation, composed of four metal rosettes with ten pins each one, which are fixed to the outside of the rim of each tire through supports. Either rosette had a jumping sensor, inductive sensors model LM12-3004PC, where each pin passing through the sensor counted as a pulse, resulting in a complete revolution after ten pulses. Furthermore, a load cell with capacity of $50 \mathrm{kN}$ was used to measure the drawbar performance. The data collected by the sensors installed in the tractor were transmitted to a central and subsequently registered. The equipment used was a datalogger, model CR 1000, Campbell Scientific brand, which is an electronic data recorder that stores the sensor data in a predefined time interval or configures an internal programming logic.

Homogeneous areas were outlined and three working depths were evaluated. These were the second experimental factor, represented by the following levels: (a) Depth 1: $0.25 \mathrm{~m}$, (b) Depth 2: $0.35 \mathrm{~m}$, and (c) Depth 3: $0.45 \mathrm{~m}$. Depths were control through the placement of metal shims in the hydraulic piston responsible for lowering and suspending the chisel plow, acting as a depth limiter. Fifty meter paths were established, where values were determined for the parameters of the traction pull required, actual travel speed and slippage of the tractor-implement set.

The experimental design was a completely randomized factorial $(2 \times 3)$ with five replications, and the acquired data were analyzed using the statistical package NTIA/EMBRAPA. The assumptions of the mathematical model (random error estimated, homogeneity of variance of estimated errors, additivity of the mathematical model and normality of the distribution of estimated errors) were observed.

\section{Results and Discussion}

Based on statistical analysis, it was possible to observe that the assumptions of the mathematical model were all met, confirming the validation of the hypotheses' inferences and tests. The accuracy of the experiment estimated by the coefficient of variation was high (Table 2) for all variables characterizing good quality.

Table 2. Mean squares for the variables of slippage, speed, power, and traction to the effects of soil type, working depth $(\mathrm{cm})$, experimental error, mean and coefficient of variation (\%) of the experiment for the 5 shanks ASA-CR LASER chisel plow. Santa Maria and Não-Me-Toque, RS, 2005

\begin{tabular}{lllll}
\hline Causes of variations & Speed $\left(\mathrm{km} \mathrm{h}^{-1}\right)$ & Slip (\%) & Pull $(\mathrm{kN})$ & Power $(\mathrm{kW})$ \\
\hline Soil type & $5.40^{*}$ & $248.41^{*}$ & $3642087.69^{*}$ & $1016.60^{*}$ \\
Working depth & $1.87^{*}$ & $81.67^{*}$ & $529874.00^{*}$ & $37.94^{\text {ns }}$ \\
Soil type x Working depth & $0.06^{*}$ & $1.48^{\text {ns }}$ & $529874.00^{*}$ & $8.21^{\text {ns }}$ \\
Block & $0.05^{*}$ & $2.18^{\text {ns }}$ & $7073.23^{\text {ns }}$ & $9.10^{\text {ns }}$ \\
Error & 0.01 & 0.80 & 6951358.77 & 15.20 \\
Mean & 4.65 & 31.46 & 33.71 & 42.98 \\
CV $(\%)$ & 2.68 & 2.85 & 7.82 & 9.07 \\
\hline
\end{tabular}

Note. ${ }^{*}=$ Significant effect on the $5 \%$ level of error probability by $\mathrm{F}$ test; ${ }^{\mathrm{ns}}=$ non significant effect by $\mathrm{F}$ test on the $5 \%$ level of error probability. 
There was no interaction between the factors soil type and working depth among the parameters analyzed, thus, there were no statistical differences among the responses of working depths both in clayey soils and in sandy soils. Therefore, the main effect of each factor was analyzed distinctly.

The travel speed of the mechanized assembly has linearly reduced to the extent that working depths of rods increased under conditions of both types of soils analyzed (Figure 1a). Similarly, Owen (1989) has determined that the forward speed of the implement was highly correlated with specific operational resistance for loam-clayey soils and loam-sandy compacted soils. That is, the greater the drawbar pull required, the lower the actual speed of work, the drawbar power demanded to the same depth depends on the travel speed and not on the water content in soil (Machado et al., 1996). In general, as the results obtained in this study, it is observed that the greater the depth of chiseling, the lower the travel speed of the mechanized assembly, mainly due to the increased tendency of occurrence of larger slippage of the tractor drive wheels on the soil and higher soil area mobilized by the implement. Meanwhile, in a study of operations performed by subsoiler shanks (Sasaki, Gonçalves, \& Betivenha, 2005), the mobilized soil area is directly related to the depth of tillage. The effects of chiseling and subsoiling are seen more clearly as compared to treatment with no tillage, on these treatments the cone index was statistically different $(\mathrm{P}<0.01)$ at different soil depths: $300 \mathrm{~mm}$ of chiseling and $400 \mathrm{~mm}$ for subsoiling (Botta, Tolon-Becerra, Lastra-Bravo \& Tourn, 2010).

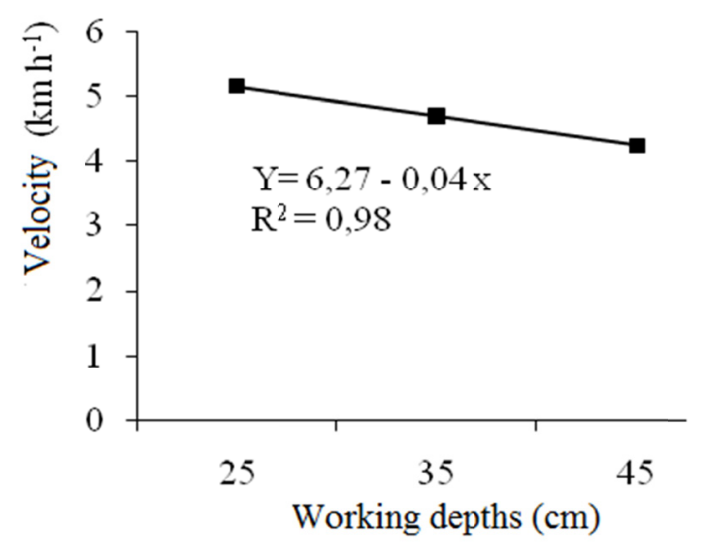

(a)

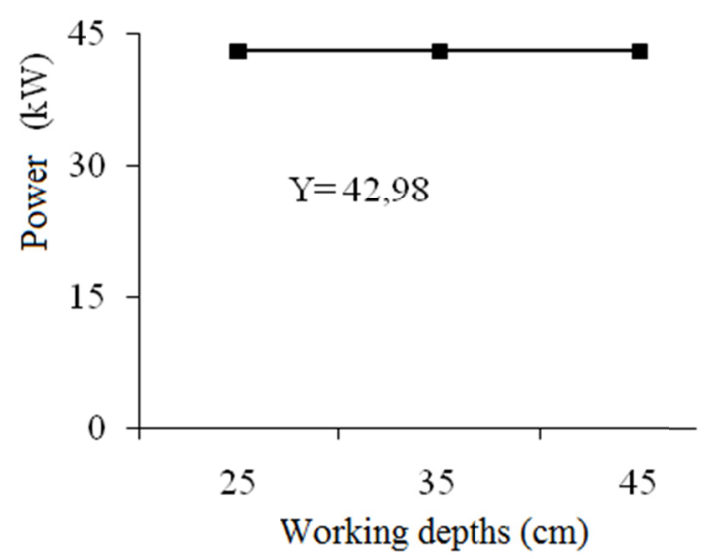

(c)

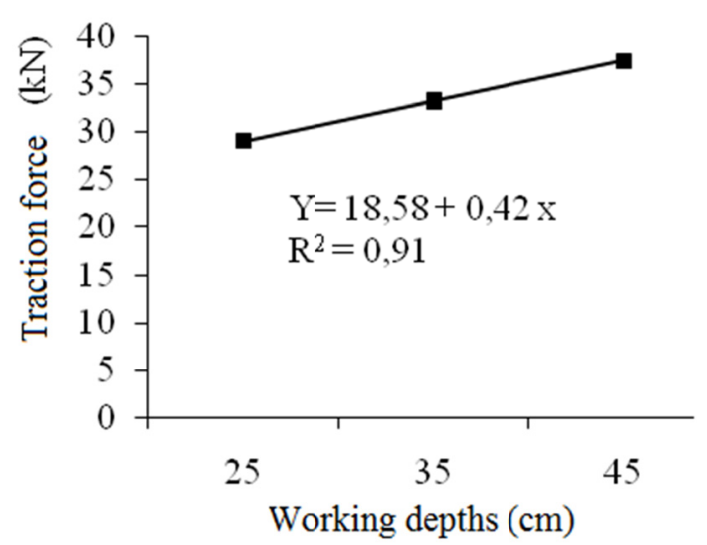

(b)

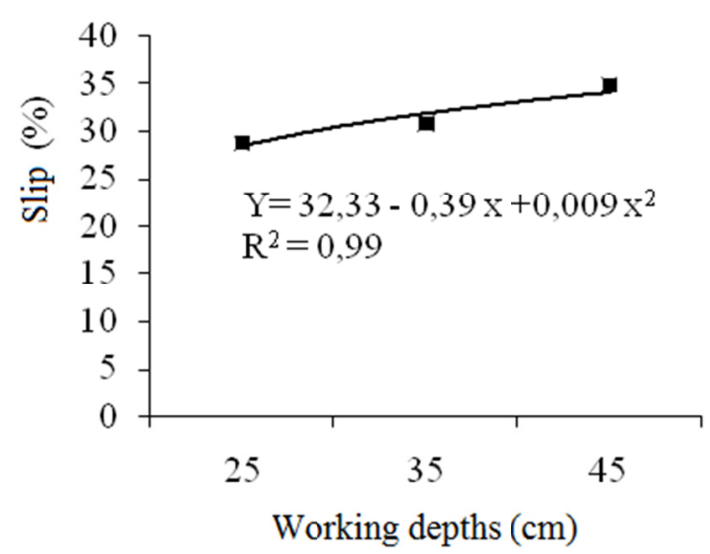

(d)

Figure 1. Behavior of scarifier in different working depths as a function of speed (a), drawbar pull (b), drawbar power (c), and slippage (d)

Unlike the results observed for the travel speed, the drawbar pull demand parameter showed linear increase with increasing working depth (Figure $1 \mathrm{~b}$ ) and with a high coefficient of determination (0.91). In a study with a chisel plow endowed with five operating shanks on alluvial soil with approximately $60 \%$ clay, significant variation was found for drawbar pull, from $12.77 \mathrm{kN}$ to $18.16 \mathrm{kN}$, when working depth varied only $60 \mathrm{~mm}$, from $270 \mathrm{~mm}$ to $330 \mathrm{~mm}$, respectively (Bianchini, Mantovani, \& Martin, 1996). Therefore, data observed in this study are in 
agreement with ASAE (1995), which describes methods to estimate the drawbar pull to chisels through mathematical models, in which working depth is the explanatory variable. However, for example, models to estimate the drawbar pull to disc plows, where travel speed is considered the main factor influencing the traction pull required.

Soil type affected drawbar pull demand in subsoiling when assessing the effect of subsoiler shanks for soil tillage (Dransfield, Willatt, \& Willis, 1965). In soils with low density, linear increase was noted for drawbar pull with working depth, but in soils of higher density, this relationship was not found. However, on a chiseling work with shanks spaced at $50 \mathrm{~cm}$, in operation depths 160 and $240 \mathrm{~mm}$ in soil with clay content of around $40 \%$, there is a decrease in the specific resistance with increasing operation depth and a non significant variation in drawbar pull (Spoor \& Godwin, 1978). Considering that the drawbar power required is a dependent variable of the behavior of travel speed and traction force (power $=$ force $\times$ speed), and taking into account that both showed an inverse relationship between themselves, the power demanded by the implement remained constant for the three working depths (Figure 1c).

Slippage showed increasing quadratic behavior (Figure 1d) increasing the lack of adhesion of the wheels on the ground with increasing working depth. Since the greater the demand for traction, the greater tends to be the value of slippage negatively interfering on tractor traction efficiency. The value of slippage influences fuel consumption (Reis et al. 1999).

Water content and soil type are the most influential variables in soil tillage operations (Srivastava, Goering, \& Rohrbach, 1993; Cholaky, Cisneros \& Balbuena, 2010). The highest values of slippage, power and traction pull (Table 3) are found for the clayey soil, statistically differing of sandy soil. The power and strength required for tillage implements vary according to depth of soil type and travel speed (Botta et al., 2010), similar to research conducted on two different soils regarding texture (sandy and clay), clayey soil was noticed to have higher pull traction (Stafford, 1979).

Table 3. Mean for slippage, travel speed, power, and traction for a chisel plow submitted to working on sandy and clayey soils for the five shanks ASA-CR LASER chisel plow. Santa Maria and Não-Me-Toque, RS. 2005.

\begin{tabular}{lllll}
\hline Soil type & Speed $\left(\mathrm{km} \mathrm{h}^{-1}\right)$ & Slippage $(\%)$ & Traction $(\mathrm{kN})$ & Power $(\mathrm{kW})$ \\
\hline Sandy & $5.09 \mathrm{a}$ & $28.48 \mathrm{~b}$ & $27.64 \mathrm{~b}$ & $38.72 \mathrm{~b}$ \\
Clayey & $4.21 \mathrm{~b}$ & $34.44 \mathrm{a}$ & $40.26 \mathrm{a}$ & $47.25 \mathrm{a}$ \\
\hline
\end{tabular}

Means followed by different lowercase in the columns differ according to the $\mathrm{F}$ test $(5 \%)$.

The sandy soil allowed greater travel speed, featuring enhanced ease of operation with the chisel and consequently requiring less power from the tractor engine, resulting in lower demand for traction pull by the implement. Thus, it is estimated that operations with such chisel plow in sandy soil demand less fuel consumption. Likewise, Bentivenha, Gonçalves, and Sazaki, (2003) in a comparison work between red yellow Oxisol with medium texture and Psament, determined that the type of soil has a great influence on the operating performance of three subsoilers, and Psament showed the best results for the variables depth, relative soil breaking and effective field capacity. When assessing the operating performance of three subsoilers in two soils (Psament and red Oxisol).

Sasaki, Bentivenha, and Gonçalves (2002) found that Psament had the best operational results for parameters of drawbar pull, travel speed, and drawbar power, even when it has higher humidity compared to the Oxisol.

In different soils (sandy and clay), at $350 \mathrm{~mm}$ depth, engine output increased by $18 \%$ on average from about 28 $\mathrm{kW}$ per shank of curved profile to about $36 \mathrm{~kW}$ per shank of straight profile. Moreover, one important factor in the energy requirement is the horizontal pressure from the tip of the shank against the ground, which significantly increased shear force (Botta, Jorajuria, Balbuena, \& Rosatto, 2004).

Travel speed (transmission gear selection) hit the tractor fuel consumption and therefore the costs of crop productivity rate of subsurface plantation with two subsoiling implements. When working at high speed, generated an increase in drawbar pull, fuel consumption, torque and shaft power, mostly, horizontal load resistance, power required and fuel consumption of the tractor increased with travel speed for both of them. However, the statistical differences observed among the vertical forces of implements were evident with the final depth of tillage (Kichler, Fulton, Raper, McDonald, \& Zech, 2011). 


\section{Conclusion}

In operations performed with chisel plow, the soil type has no effect on the response of the parameters of drawbar pull, travel speed, drawbar power required, and slippage even in different working depths. Chisel plow drawbar pull demand increases while travel speed reduces with greater working depths. Drawbar power required has no influence on working depth.

Clayey soils showed higher values of slippage, drawbar power, and drawbar pull, statistically differing of chiseling in sandy soil.

\section{References}

ASAE (American Society of Association Executives). (1994). Soil Cone Penetrometer (ASAE Standards S313.3, 42nd ed., 1995, p. 683). St. Joseph, Michigan: ASAE.

ASAE (American Society of Association Executives). (1995). Agricultural Machinery Management Data. Draft and power requirements (ASAE Standards D497.2, 42nd ed., 1995, p. 337). St. Joseph, Michigan: ASAE.

Bentivenha, S. R. P., Gonçalves, J. L. M., \& Sazaki, C. M. (2003). Mobilização do solo e crescimento inicial do eucalipto em função do tipo de haste subsoladora, profundidade de trabalho e características do solo. Engenharia Agrícola, 23(3), 588-605.

Bianchini, A., Mantovani, E., \& Martin, P. J (1996). Avaliação de desempenho de um escarificador em solo aluvial. Agricultura Tropical, 2(1), 61-70.

Bianchini, A., Sabino, M. H. C., Borges, P. H. M., \& Sguarezzi, J. J. (1999). Comportamento operacional de um escarificador de hastes parabólicas em solo de cerrado. Revista Brasileira de Engenharia Agrícola e Ambiental, 3(3), 395-401. https://doi.org/10.1590/1807-1929/agriambi.v3n3p395-401

Bogunovic, I., Pereira, P., Kisic I., Sajk, K., \& Sraka, M. (2018). Tillage management impacts on soil compaction, erosion and crop yield in Stagnosols (Croatia). Catena, 160, 376-384. https://doi.org/10.1016/ j.catena.2017.10.009

Botta, G. F., Tolon-Becerra, A., Lastra-Bravo, X., \& Tourn, M. (2010). Tillage and traffic effects (planters and tractors) on soil compaction and soybean (Glycine max L.) yields in Argentinean pampas. Soil \& Tillage Research, 110, 167-174. https://doi.org/10.1016/j.still.2010.07.001

Botta, G., Jorajuria, D., Balbuena, R., \& Rosatto, H. (2004). Mechanical and cropping behaviour of direct drilled soil under different traffic intensities: Effect in soybean (Glycine max L.) yields. Soil \& Tillage Research, 78, 53-58. https://doi.org/10.1016/j.still.2004.01.004

Celik, I., Günal, H., Acar, M., Gök, M., Bereket Barut, Z., \& Palmiralan, H. (2017). Long-term tillage and residue management effect on soil compaction and nitrate leaching in a Typic Haploxerert soil. International Journal of Plant Production, 11(1), 131-150. https://doi.org/10.22069/IJPP.2017.3314

Cholaky, C., Cisneros, J. M., \& Balbuena, R. (2010). Field performance of a winged scarifier as a function of soil compaction and water content. Chilean Journal of Agricultural Research, 70(1), 150-158. https://doi.org/10.4067/S0718-58392010000100016

Dransfield, P., Willatt, S. T., \& Willis, A. H. (1965). Soil to implement reaction experienced with simple tines at various angles of attack. Journal of Agriculture Engineering Research, 9, 220-234.

EMBRAPA (Empresa Brasileira de Pesquisa Agropecuária). (1997). Manual de métodos de análise de solo (p. 212).

EMBRAPA (Empresa Brasileira de Pesquisa Agropecuária). (1999). Sistema Brasileiro de Classificação de Solos (p. 412).

Filho, A. C., Centurion J. F., Silva R. P., Furlani C. E. A., \& Carvalho L. C. C. (2007). Métodos de preparo do solo: Alterações da rugosidade do solo. Engenharia Agricola, 27(1), 229-237. https://doi.org/10.1590/ S0100-69162007000100017

Gregory, A. S., Ritz, K., McGrath, S. P., Quinton, J. N., Goulding, K. W. T., Jones, R. J. A., ... Whitmore A. P. (2015). A review of the impacts of degradation threats on soil properties in the UK. Soil Use and Management, 31(Suppl. 1), 1-15. https://doi.org/10.1111/sum.12212

Kichler, C. M., Fulton, J. P., Raper, R. L., McDonald, T. P., \& Zech, W. C. (2011). Effects of transmission gear selection on tractor performance and fuel costs during deep tillage operations. Soil \& Tillage Research, 113, 105-111. https://doi.org/10.1016/j.still.2011.03.002 
Machado, R. L. T., Machado, A. L. T., Turatti, A. L., Reis, A. V., \& Alonço, A. S. (1996). Avaliação do desempenho de escarificador em planossolo. Revista Brasileira de Agrociência, 2(3), 151-154. https://doi.org/10.18539/CAST.V2I3.169

Márquez, L. (2012). Tractores Agrícolas: Tecnologia y Utilización (p. 844). B\&H Editores.

Owen, G. T. (1989). Subsoiling forces and tool speed in compact soils. Canadian Agricultural Engineering, 31(1), 15-20.

Ranjbarian, S., Askari, M., \& Jannatkhah, J. (2017). Performance of tractor and tillage implements in clay soil. Journal of the Saudi Society of Agricultural Sciences, 16, 154-162. https://doi.org/10.1016/j.jssas.2015. 05.003

Reis, A. V., Machado A. L. T., Moraes, M. L. B., \& Tillmann, C. A. C. (1999). Motores, tratores, combustíveis e lubrificantes (p. 315). Pelotas: Ed. Universitária/UFPEL.

Sasaki, C. M., Bentivenha, S. R. P., \& Gonçalves, J. L. M. (2002). Configurações básicas de subsoladores florestais. In J. L. M. Gonçalves, \& J. L. Stape (Eds.), Conservação e cultivo de solos para plantaçães florestais (Cap. 12, pp. 393-407). Piracicaba, Brazil: IPEF.

Sasaki, C. M., Gonçalves, J. L. M., \& Bentivenha, S. R. P. (2005). Desempenho operacional de hastes subsoladoras em função da ponteira e do tipo do solo. Scientia Forestalis, 67, 44-52.

Souza, L. H., Rabelo, C. G., Cabacinha, C. D., Pinto, M. J. S., \& Matos, L. (2015). Consumo de combustível em trator agrícola em função da velocidade e profundidade de trabalho nas operações de aração e gradagem. Engenharia na Agricultura, 23(1), 65-70. https://doi.org/10.13083/reveng.v23i1.502

Sowers, G. F. (1965). Consistenc. In C. A. Black, et al. (Eds.), Methods of soil analysis (Part 1, pp. 391-399). Madison, Wisconsin: Amercian Society of Agronomy.

Spoor, G., \& Godwin, R. J. (1978). An experimental investigation in the dup haseming of by rigid times. Journal of Agricultural Engineering Research, 23, 243-58. https://doi.org/10.1016/0021-8634(78)90099-9

Srivastava, A. K., Goering, C. E., \& Rohrbach, R. P. (1993). Engineering principles of agricultural machines (p. 602). Michigan: ASAE (American Society of Agricultural Engineers).

Stafford, J. V. (1979). The performance of a rigid time in relation to soil properties and speed. Journal of Agricultural Engineering Research, 24, 41-55. https://doi.org/10.1016/0021-8634(79)90059-3

Trouse Jr., A. C., \& Humbert, R. P. (1959). Deep tillage in Hawaii: 1. Subsoiling. Soil Science, Baltimore, 88(3), 150-159. https://doi.org/10.1097/00010694-195988030-00006

Unger, P. W., \& Mccalla, T. M. (1981). Conservation tillage systems. Advances in Agronomy, 33, 1-57. https://doi.org/10.1016/S0065-2113(08)60163-7

\section{Copyrights}

Copyright for this article is retained by the author(s), with first publication rights granted to the journal.

This is an open-access article distributed under the terms and conditions of the Creative Commons Attribution license (http://creativecommons.org/licenses/by/4.0/). 